\title{
Effect of top-down control on cell-specific activity and diversity of active marine bacterioplankton
}

\author{
Krista Longnecker $^{1,3, *}$, Michelle J. Wilson ${ }^{2,4}$, Evelyn B. Sherr ${ }^{1}{ }^{\text {, Barry F. Sherr }}{ }^{1}$ \\ ${ }^{1}$ College of Oceanic and Atmospheric Sciences, Oregon State University, 104 COAS Admin Bldg, Corvallis, Oregon \\ 97331, USA \\ ${ }^{2}$ Department of Chemical Engineering, Oregon State University, Corvallis, Oregon 97331, USA \\ ${ }^{3}$ Present address: Woods Hole Oceanographic Institution, Marine Chemistry and Geochemistry, 360 Woods Hole Road MS\#4, \\ Woods Hole, Massachusetts 02543, USA \\ ${ }^{4}$ Present address: Chemical and Biological Engineering Department, University of Wisconsin-Madison, Madison, Wisconsin \\ 53706, USA
}

\begin{abstract}
Mortality processes such as grazing and viral lysis can alter both phylogenetic diversity and cell-specific activity of bacterioplankton. We conducted experiments to examine the effect of reduction in grazer or viral abundance on metabolically active bacterioplankton at a eutrophic shelf station and an oligotrophic basin station. Leucine assimilation was used as a proxy to characterize metabolically active bacterial cells. The phylogenetic affiliation of marine bacterioplankton assimilating leucine was identified with fluorescence in situ hybridization and microautoradiography. Flow cytometric sorting of leucine-labeled cells quantified cell-specific activity of high nucleic acid (HNA) and low nucleic acid cells. The activity and diversity of the bacterial community at the oligotrophic station was more responsive to a reduction in mortality compared to the community at the eutrophic station. HNA cells at the oligotrophic station showed a 4 -fold increase in cell-specific leucine incorporation when the abundance of flagellates was reduced and an 8-fold increase when the abundance of flagellates, viruses, and bacterial cells was reduced. The abundance of active Alphaproteobacteria increased at the oligotrophic station when either grazer or viral abundance was reduced. Activity responses were less striking at the eutrophic station, and the abundance of active Gammaproteobacteria showed a greater increase with reduced flagellates compared to the treatment with reduced flagellates, viruses, and bacterioplankton. Our results indicate both the presence and type of mortality process play a key role in structuring a bacterial community, and this effect varies in ecosystems of differing trophic state.
\end{abstract}

KEY WORDS: Marine bacterioplankton · Top-down control $\cdot$ Leucine incorporation · Flow cytometry · Microautoradiography · Fluorescence in situ hybridization · Grazing · Viral lysis

Resale or republication not permitted without written consent of the publisher

\section{INTRODUCTION}

Marine bacterioplankton are a significant component of the biosphere, both in terms of biomass and activity (Whitman et al. 1998). However, the fact that individual bacterial cells can exhibit a range of metabolic states, from dormancy to rapid growth, complicates our understanding of the activity of bacterioplankton assemblages (Sherr et al. 1999a, del Giorgio \& Bouvier 2002, del Giorgio \& Gasol 2008). To assess the role of microorganisms in biogeochemical cycling, more research is needed into the factors controlling the diversity and cell-specific activity of metabolically active bacterial cells. Most attention in this regard has been on bottom-up control (substrate availability), with less attention given to bacterial interactions with other segments of a microbial community (Strom 2008). Therefore, the effect of mortality from protist grazing and/or viral lysis on bacterial activity and diversity is still not well understood. 
Protocols involving a combination of fluorescence in situ hybridization (FISH) with microautoradiography allow identification of metabolically active phylogenetic groups within marine bacterioplankton (e.g. Ouverney \& Fuhrman 1999, Cottrell \& Kirchman 2000). This approach has provided important insights into both spatial (Elifantz et al. 2007, Varela et al. 2008) and temporal (Alonso-Sáez \& Gasol 2007) variability in the diversity of active bacterial cells. In previous work in the Oregon upwelling system, we found little spatial variability in the diversity of active cells (Longnecker et al. 2005), although the abundance of active cells increased with ecosystem trophic state (Longnecker et al. 2006a). These findings raised the question of the relative importance of top-down (mortality) versus bottom-up (substrate availability) processes in eutrophic compared to oligotrophic marine ecosystems.

In addition to the qualitative information derived from FISH analysis, flow cytometric sorting of radioactively labeled cells based on nucleic acid content can yield quantitative information on cell-specific metabolic activity. Flow cytometric analysis generally identifies 2 groups of bacterial cells: cells with high nucleic acid (HNA) content and cells with low nucleic acid (LNA) content (Li et al. 1995, Gasol \& del Giorgio 2000). Results based on flow cytometric sorting of radioactively labeled bacterioplankton from in situ marine systems (Lebaron et al. 2001, Lebaron et al. 2002, Servais et al. 2003) and from mesocosm experiments (Servais et al. 1999) indicate that HNA cells generally have higher cell-specific incorporation rates compared to LNA cells. However, LNA cells can also be active members of heterotrophic microbial communities (Jochem et al. 2004, Longnecker et al. 2005, Mary et al. 2006).

Top-down processes (grazing and viral lysis) can structure bacterial communities. In the Oregon (USA) upwelling system, as in most marine habitats, bacterivorous flagellates are the dominant grazers of marine bacterioplankton (Suzuki 1999). Such grazers can alter both bacterial community composition and activity (Sherr et al. 1992, Suzuki 1999, Jürgens \& Matz 2002, Beardsley et al. 2003, Vázquez-Domínguez et al. 2005). Grazers selectively consume larger (Monger \& Landry 1992, González 1996) and more active bacterial cells (Sherr et al. 1992, González et al. 1993, del Giorgio et al. 1996). Results from both experiments and in situ samples reveal increases in grazing pressure are positively correlated with HNA bacterial abundance and biomass (Vaqué et al. 2001). However, contradictory observations have been published regarding the response of LNA cells to grazing. LNA cells were not correlated to changes in grazing rate in experimental or in situ samples (Vaqué et al. 2001). However, LNA cells can be grazed at rates which are higher than or equal to (Jochem et al. 2004, Scharek \& Latasa 2007) as well as lower than (Williams et al. 2008) the grazing rates for HNA cells. What causes the different response of protist grazers to LNA cells is not yet clear.

Viruses are abundant within marine ecosystems, although quantifying their effect on bacterial community diversity and activity remains a challenge (Fuhrman 1999, Suttle 2007). The amount of bacterial mortality attributed to viruses can be equivalent to bacterial mortality due to protist grazing (Fuhrman \& Noble 1995). There is also increasing evidence that viruses and grazers interact with each other in addition to their effect on bacterial cells (Miki \& Jacquet 2008). Indeed, the presence of grazers has been shown to increase viral production (Weinbauer et al. 2003), further complicating examination of the interactions between viruses and a bacterial community. In a freshwater incubation experiment, removing both flagellates and viruses did not change the percent of HNA cells beyond those changes observed when only flagellates were removed (Šimek et al. 2007). In addition, in incubations with viruses, the abundance of metabolically active Betaproteobacteria decreased over time as the community shifted to a metabolically active filamentous Flectobacillus (Šimek et al. 2007).

The goal of the present study was to examine the role of top-down control processes in structuring bacterial cell-specific activity and the diversity of metabolically active bacterioplankton in marine systems of differing trophic states. We set up experiments in which protist grazing rates and/or protist grazing and viral infection rates were reduced at a eutrophic shelf station and an oligotrophic basin station. Our results revealed that removing grazers altered the diversity of the metabolically active bacterial cells at both stations, but reducing viral abundances primarily affected cellspecific activity and only did so at the oligotrophic station.

\section{MATERIALS AND METHODS}

Environmental parameters. Seawater was collected from a depth of $10 \mathrm{~m}$ at 2 sites off the Oregon coast, USA, in September 2004, using General Oceanics 51 Niskin bottles mounted on a rosette equipped with a SeaBird SBE 911+CTD. The first site was on the shelf, $5 \mathrm{~km}$ from shore, with a bottom depth of $54 \mathrm{~m}\left(44^{\circ} \mathrm{N} 124.2^{\circ} \mathrm{W}\right)$. The second site was a basin station above the abyssal plain, $237 \mathrm{~km}$ from shore, with a bottom depth of $2940 \mathrm{~m}$ $\left(44^{\circ} \mathrm{N} 127.1^{\circ} \mathrm{W}\right)$.

Seawater for nutrient and chlorophyll a (chl a) analysis was collected prior to establishing the experimental treatments. For nutrients, seawater was frozen in $60 \mathrm{ml}$ high-density polyethylene bottles until analyses were 
conducted on shore. Analyses for concentration of nitrate + nitrite, ammonium, phosphate, and silicic acid (silicate) were performed using a hybrid Technicon AutoAnalyzerII ${ }^{\mathrm{TM}}$ and Alpkem RFA300 ${ }^{\mathrm{TM}}$ system following protocols modified from Gordon et al. (1994). For determination of chl a concentrations, subsamples of whole seawater were vacuum filtered onto $25 \mathrm{~mm}$ Whatman GF/F filters which were stored frozen at $-80^{\circ} \mathrm{C}$ until processed on shore. Chl a was extracted for $>12 \mathrm{~h}$ in the dark at $-20^{\circ} \mathrm{C}$ using $90 \%$ acetone as the solvent (Strickland \& Parsons 1972). Fluorescence was measured with a Turner Designs ${ }^{\mathrm{TM}}$ 10-AU fluorometer calibrated with purified chl a (Sigma).

Experimental setup. The present study used experimental manipulations of seawater collected off the Oregon coast; the shelf station and the basin station experiments were set up within a period of $3 \mathrm{~d}$. For each experiment, 3 treatments were established in pre-soaked and rinsed 9.51 low-density polyethylene cubitainers: whole seawater (control treatment), a 1:1 mixture of whole seawater with seawater twice filtered through $0.8 \mu \mathrm{m}$ polycarbonate filters (reduced flagellates treatment), and a 1:1 mixture of whole seawater with seawater filtered through a $30 \mathrm{kDa}$ tangential flow filter (reduced flagellates/virus/bacterioplankton treatment, hereafter 'reduced FVB'). This setup resulted in 3 cubitainers for the shelf experiment and 3 for the offshore experiment. The cubitainers were placed in a darkened on-deck incubator flushed continuously with surface seawater. During the experiments, water temperatures in the on-deck incubator averaged $17^{\circ} \mathrm{C}$ at the shelf and $18^{\circ} \mathrm{C}$ at the basin station. Samples were collected daily from the cubitainers, starting with time zero and ending $4 \mathrm{~d}$ later. At each sampling point, water was collected for cell counts and incubations with radioactive leucine.

Samples for enumeration of heterotrophic flagellates were preserved by a 3-step process (Sherr \& Sherr 1993): cells were first preserved with $0.05 \%$ (final concentration) alkaline Lugol's solution, followed by $0.1 \%$ (final concentration) sodium thiosulfate, and finally $2 \%$ (final concentration) borate-buffered formaldehyde. Preserved samples were incubated at $4^{\circ} \mathrm{C}$ for $24 \mathrm{~h}$, stained with DAPI ( $25 \mu \mathrm{g} \mathrm{ml}^{-1}$ final concentration) for $10 \mathrm{~min}$, and then filtered onto black $0.8 \mu \mathrm{m}$ polycarbonate filters (Sherr et al. 1993). Slides were frozen at $-20^{\circ} \mathrm{C}$ until examination with an Olympus BX-61 epifluorescence microscope.

A Becton-Dickinson FACSCalibur flow cytometer was used for all enumeration and sorting of bacterial cells as previously described (Longnecker et al. 2005). For enumeration, $3 \mathrm{ml}$ sample aliquots were fixed with $0.2 \% \mathrm{w} / \mathrm{v}$ paraformaldehyde (final concentration), stored in the dark for at least $10 \mathrm{~min}$ at room temperature to harden cells, frozen in liquid nitrogen, and stored at $-80^{\circ} \mathrm{C}$ until sample processing on shore. After thawing, 3 water samples from each cubitainer were stained with a $1 \times$ working stock of SYBR Green I (Invitrogen) and $25 \mathrm{mM}$ potassium citrate for $15 \mathrm{~min}$ following a protocol modified from Marie et al. (1997). The abundance of cells was determined by calculating the flow rate with known concentrations of $1 \mu \mathrm{m}$ fluorescent microspheres (Polysciences). Regions established on cytogram plots of side scatter versus green fluorescence were adjusted for each sample in order to define bacterial cells with HNA and LNA content. Abundances of virus-like particles were also obtained from the flow cytometry data using the regions defined by Seymour et al. (2005). For some of the samples, we were able to identify different viral populations. These different populations were not consistently observed; therefore, we consider all of the virus-like particles as one population. In addition to abundance, mean side scatter and green fluorescence values were obtained for HNA and LNA cells in each sample. Data for side scatter and green fluorescence were normalized to the side scatter and fluorescence of the microspheres to minimize between-sample variability.

Sorting bacterial cells labeled with ${ }^{3} \mathrm{H}$-leucine. For analysis of cell-specific leucine incorporation rates of HNA and LNA bacterial cells, seawater samples collected from each cubitainer were incubated immediately after collection with $40 \mathrm{nM}{ }^{3} \mathrm{H}$-leucine (specific activity $170 \mathrm{Ci} \mathrm{mmol}{ }^{-1}$, Perkin Elmer Life Science Products) as previously described (Longnecker et al. 2006b). Cells were then fixed with $0.2 \% \mathrm{w} / \mathrm{v}$ paraformaldehyde (final concentration) and transported back to the lab frozen at $-80^{\circ} \mathrm{C}$. All flow cytometric sorts were run on low flow using the Single Cell option of the Becton-Dickinson Cell Quest software (Longnecker et al. 2005, 2006b). Prior to sorting, aliquots of each thawed sample were incubated in the dark for 15 min with a $1 \times$ working stock of SYBR Green I. Bacteria were separately sorted from HNA and LNA regions onto $25 \mathrm{~mm}, 0.2 \mu \mathrm{m}$ cellulose acetate membranes using the Becton-Dickinson cell concentrator unit attached to the flow cytometer's sort line. A total of $1.0 \times 10^{5} \mathrm{SYBR}$-stained cells were sorted for each region; the sorting process was repeated using 3 different aliquots from each cubitainer. Sorts lasted from 10 to $75 \mathrm{~min}$; during longer sorts we placed a freshly stained aliquot of the sample on the flow cytometer every $15 \mathrm{~min}$.

After collection of the target number of cells, the membrane filter was removed from the cell concentrator unit, transferred to a filter manifold, and processed following the method of Kirchman (1993). The filter was washed twice with cold $5 \%$ trichloroacetic acid (TCA) and twice with cold $80 \%$ ethanol, folded into a $7 \mathrm{ml}$ scintillation vial, and allowed to dry. Ethyl acetate 
$(0.5 \mathrm{ml})$ was added to the scintillation vial to dissolve the filter, followed by $4 \mathrm{ml}$ of scintillation cocktail (Ultima Gold LLT, PerkinElmer). The samples were allowed to sit for $2 \mathrm{~d}$ before counting on a Wallac 1141 LSC. For each sample, the disintegrations per minute (DPM) of an unsorted TCA-killed vial was subtracted from the DPM of the cell sorts for that sample. Cellspecific leucine incorporation rates were obtained by dividing the molar incorporation rate determined for each filter by the number of cells sorted for that sample.

Microautoradiography and FISH (MICROFISH). We have modified existing protocols combining microautoradiography and FISH (Longnecker et al. 2006a). Between 8 and $10 \mathrm{ml}$ of seawater was filtered onto $0.2 \mu \mathrm{m}$ polycarbonate filters placed on top of $0.45 \mu \mathrm{m}$ backing filters. A razor blade was used to cut each filter into 8 sections which were then mounted onto glass slides. Six different Cy3-labeled probes were used: ALF968 (Alphaproteobacteria, Glöckner et al. 1999), Bet42a (Betaproteobacteria, Manz et al. 1992), CFB319a (Cytophaga-like, Manz et al. 1992), Gam42a (Gammaproteobacteria, Manz et al. 1992), EUB338 (Bacteria, Amann et al. 1990), and a negative control designed by Karner \& Fuhrman (1997). Competitor probes were not used for the Gam42a and Bet42a probes. The hybridizations were incubated overnight at $42^{\circ} \mathrm{C}$; all washes were done at $48^{\circ} \mathrm{C}$, except for the EUB338 and the negative control probes which were washed at $50^{\circ} \mathrm{C}$. The hybridization buffer contained $0.9 \mathrm{M} \mathrm{NaCl}, 20 \mathrm{mM}$ Tris ( $\mathrm{pH}=7.4), 0.01 \%$ sodium dodecyl sulphate (SDS), and formamide concentrations as follows: $15 \%$ formamide for EUB338 and the negative control, $35 \%$ formamide for ALF968 and CFB319a, and 30\% formamide for Bet42a and Gam42a. Following the initial hybridization, slides were washed twice with $20 \mathrm{mM}$ Tris ( $\mathrm{pH}=7.4), 0.01 \%$ SDS, and $\mathrm{NaCl}$ and EDTA concentrations as follows: $150 \mathrm{mM} \mathrm{NaCl}$ and $6 \mathrm{mM}$ EDTA for EUB338 and the negative control, $80 \mathrm{mM} \mathrm{NaCl}$ and $5 \mathrm{mM}$ EDTA for ALF968 and CFB319a, or $102 \mathrm{mM} \mathrm{NaCl}$ and $5 \mathrm{mM}$ EDTA for Bet42a and Gam42a. Washes were for $10 \mathrm{~min}$ each, followed by $10 \mathrm{~min}$ in $5 \mu \mathrm{g} \mathrm{ml}^{-1} \mathrm{DAPI}$ at $4^{\circ} \mathrm{C}$, and 2 min at $4^{\circ} \mathrm{C}$ Milli-Q water. The filters were allowed to dry before the next processing step. In the darkroom with a red light at least $1 \mathrm{~m}$ away, new slides were dipped into EM-1 emulsion (Amersham Pharmacia Biotech) and the filter pieces placed face-down onto the emulsion. The slides were incubated at $4^{\circ} \mathrm{C}$ for 12 to $14 \mathrm{~h}$. Following incubation, slides were developed for 4 min in Kodak D-19 developer, stopped in Milli-Q water for $10 \mathrm{~s}$, placed in Kodak fixer for $5 \mathrm{~min}$, and washed in Milli-Q water for $5 \mathrm{~min}$. After the slides were dry, the filter was removed from the slide, Citifluor was placed onto the area where the filter had been located, and the edges of the coverslip were sealed to the glass slide using nail polish.

Slides were viewed on an Olympus BX-61 epifluorescence microscope using the filter sets appropriate for DAPI and Cy3-labeled cells. Ten to 16 fields per slide were captured with a SensicamQE CCD camera (Cooke) to count at least 500 DAPI-stained cells. Image Pro Plus was used to filter the images and then threshold each image to define the location of the cells or silver grains. The masks generated by Image Pro Plus were imported into a MATLAB program designed to determine where silver grains overlapped with DAPIand/or probe-stained cells. Cells which were stained with both DAPI and Cy3-labeled probes were identified as probe-positive cells. Cells which were touching silver grains were identified as cells which had assimilated ${ }^{3} \mathrm{H}$-leucine and were therefore metabolically active. The proportion of metabolically active cells identified by each probe was then calculated by dividing the number of probe-stained cells touching or overlapping silver grain(s) by the number of DAPI-stained cells touching or overlapping silver grain(s). The errors for the proportion of cells which were probe-positive or metabolically active were calculated using the propagation of error formulas from Bevington \& Robinson (2003).

\section{RESULTS}

\section{Environmental parameters}

Two marine ecosystems of differing trophic state off the Oregon coast were chosen to examine the role of top-down control on heterotrophic bacterial activity and diversity. The shelf station had higher nutrient and chl a concentrations compared to the basin station (Table 1). In addition, higher abundances of eukaryotic phytoplankton were observed at the shelf station. Abundances of prokaryotic phytoplankton, Synechococcus and Prochlorococcus, were higher at the basin station (Table 1).

\section{Changes in microbial abundance during the incubation experiments}

The incubation experiments were sampled daily beginning with time zero until the termination of each experiment after $4 \mathrm{~d}$. Lower abundances of heterotrophic bacterial cells were observed at the basin station compared to the shelf station (Fig. 1). At the shelf station, higher abundances of heterotrophic bacterial cells were present by Day 1 of the experiment relative to the abundances measured at the beginning of the 
Table 1. Ecological differences between the 2 stations (eutrophic shelf and oligotrophic basin) where the incubation experiments were conducted. Data are from seawater collected at the beginning of each experiment prior to manipulation of the water to establish the 3 treatments. Temperature and salinity data are from the CTD; all other data are from discrete samples collected with Niskin bottles. Error estimates are given in 'Materials and methods'

\begin{tabular}{|lcc|}
\hline Variable & Shelf & Basin \\
\hline Temperature $\left({ }^{\circ} \mathrm{C}\right)$ & 15 & 19 \\
Salinity & 32.5 & 32.0 \\
Nitrate $(\mu \mathrm{M})$ & 2.4 & 0.2 \\
Phosphate $(\mu \mathrm{M})$ & 0.5 & 0.2 \\
Silicate $(\mu \mathrm{M})$ & 8.3 & 1.2 \\
Ammonium $(\mu \mathrm{M})$ & 0.65 & 0.02 \\
Chlorophyll a $\left(\mu \mathrm{g} \mathrm{l}^{-1}\right)$ & 4.3 & 0.2 \\
Eukaryotic phytoplankton $\left(\times 10^{3}{\left.\text { cells } \mathrm{ml}^{-1}\right)}^{-1}\right.$ & 5.1 & 2.8 \\
Prochlorococcus $\left(\times 10^{4} \mathrm{cells} \mathrm{ml}^{-1}\right)$ & 0 & 4.0 \\
Synechococcus $\left(\times 10^{4} \mathrm{cells} \mathrm{ml}^{-1}\right)$ & 3.0 & 7.4 \\
\hline
\end{tabular}

experiment. In the control treatment, the increase in bacterial abundance was accompanied by a higher percentage of HNA cells (Fig. 1A). However, in the reduced flagellates and reduced FVB treatments, growth of LNA cells resulted in a decrease in the percentage of HNA cells at Day 1 (Fig. 1B,C). This was a transient phenomenon, and by Day 2 higher percentages of HNA cells were observed in the reduced flagellates and reduced FVB treatments. At the offshore station, the abundances of heterotrophic bacterial cells did not increase until Day 2 of the experiment, and maximum values were observed by Day 3. The percent of HNA cells at the offshore station did not exhibit large changes over the course of the experiment (Fig. 1D-F).

Side scatter of SYBR-stained heterotrophic bacterial cells can be used as a proxy for cell size (Troussellier et al. 1999). During both the shelf and the offshore experiment, HNA cells were larger than LNA cells (Fig. 2). At the shelf station, the lowest side scatter values were measured on Day 2 (Fig. 2A-C), concurrent with the highest abundances of heterotrophic bacterial cells. At the offshore station, the largest side scatter values occurred $1 \mathrm{~d}$ before the highest bacterial abundances (Fig. $2 \mathrm{D}, \mathrm{F})$, or concurrent with the highest bacterial abundance (Fig. 2E). The largest increase in side scatter was observed for the HNA cells at the offshore station when the side scatter of heterotrophic bacterial cells doubled from its initial value to the value measured on Day 2 in the reduced FVB treatment.

At the shelf station, the experimental setup reduced the abundance of heterotrophic nanoflagellates in the reduced flagellates and reduced FVB treatments (Fig. 3). The abundance of heterotrophic nanoflagellates in the control treatment was $3.4 \pm 0.9 \times 10^{3}$ cells $\mathrm{ml}^{-1}$ (Fig. 3A); filtration reduced the abundance of heterotrophic nanoflagellates to $1.7 \pm 0.7 \times 10^{3}$ and $1.5 \pm$ $0.3 \times 10^{3}$ cells $\mathrm{ml}^{-1}$ in the shelf reduced flagellates and reduced FVB treatments, respectively (Fig. 3B, C). Flagellate abundances increased in all treatments, and reached maximum abundances on Day 3 of the experiment.

The abundance of virus-like particles was lowest in the reduced FVB treatment throughout the shelf station
Fig. 1. Changes in cell abundances of bacterioplankton (left axes, $\times 10^{6}$ cells ml-1) and percent of high nucleic acid (HNA) cells (right axes). Note the difference in range for the abundances from the shelf $(\mathrm{A}-\mathrm{C})$ and basin $(\mathrm{D}-\mathrm{F})$ stations. Three different treatments are shown: $(\mathrm{A}, \mathrm{D})$ control, $(\mathrm{B}, \mathrm{E})$ reduced flagellates, and $(\mathrm{C}, \mathrm{F})$ reduced flagellates/viruses/bacterioplankton (FVB). Error bars for the bacterial abundances represent \pm SD for counts conducted with 3 aliquots preserved from a single cubitainer 


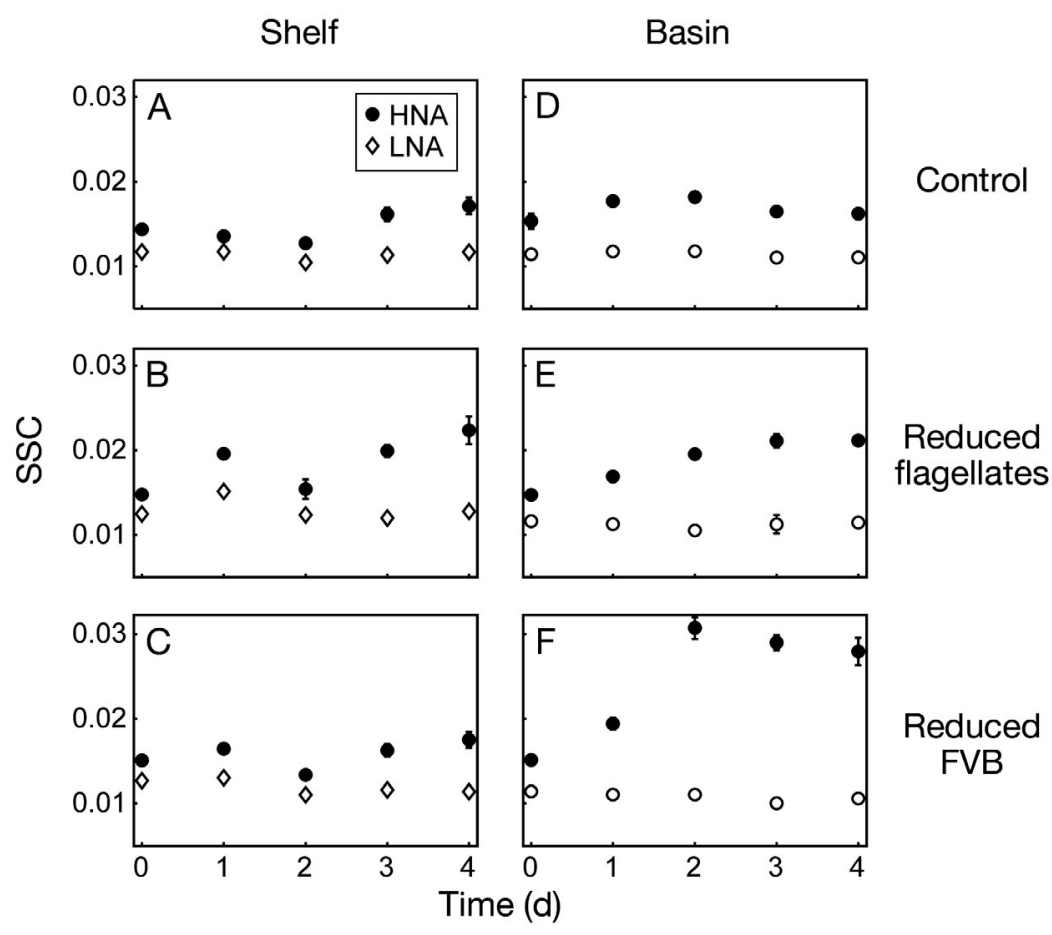

Fig. 2. Variability in side scatter (SSC), a proxy for cell size, of high (HNA) and low nucleic acid (LNA) cells for the shelf (A-C) and basin station experiments (D-F). SSC values are normalized to the fluorescent microspheres' SSC to minimize between-sample variability. Three different treatments are shown: $(\mathrm{A}, \mathrm{D})$ control, $(\mathrm{B}, \mathrm{E})$ reduced flagellates, and $(\mathrm{C}, \mathrm{F})$ reduced flagellates/viruses/bacterioplankton $(\mathrm{FVB})$. Error bars $( \pm \mathrm{SD})$ for triplicate measurements from a single cubitainer are shown, though for some of the data points they are smaller than the symbol

experiment (Fig. 3A-C). Our counts of virus-like particles are lower than other studies (e.g. data compiled in Clasen et al. 2008, Wilhelm \& Matteson 2008), and should be considered underestimates for 2 reasons. First, we did not attempt to count the abundance of virus-like particles within bacterial cells. Second, while we did dilute the samples before loading on the flow cytometer, in the flow cytometer measurements, multiple particles get incorrectly counted as single particles in regions with high particle abundance (Marie et al. 1999, Brussaard 2004). The increase in viral abundances in the reduced flagellates treatment at the shelf station is likely due to an increase in viral-sized particles introduced during the $0.8 \mu \mathrm{m}$ filtration step. In both the reduced flagellates and reduced FVB treatments, the virus:bacteria ratio decreased from the onset of the experiment until Day 2, at which point the ratio increased up to a maximum value of 5 in the reduced flagellates treatment (from data in Figs. 1 \& 3).

Lower abundances of heterotrophic nanoflagellates were observed at the basin station. The abundance of heterotrophic nanoflagellates in the control treatment was $1.7 \pm 0.5 \times 10^{3}$ cells ml ${ }^{-1}$ (Fig. 3D); filtration reduced the abundance of heterotrophic flagellates to $1.0 \pm 0.3 \times 10^{3}$ cells $\mathrm{ml}^{-1}$ in both the reduced flagellates and reduced FVB treatments (Fig. 3E,F). Flagellate abundances initially decreased in all 3 experimental setups, reaching minimum values on Day 2 or 3 with a subsequent increase in abundance. The abundance of flagellates in the control was higher than in the reduced flagellates and reduced FVB treatments for the duration of the experiment. The abundance of virus-like particles at the basin station mirrored the bacterial abundances which resulted in virus:bacteria ratios close to 1 (from data in Figs. 1 \& 3).

\section{Cell-specific incorporation of radioactively labeled leucine}

During both the shelf and basin station experiments, cell-specific leucine incorporation rates were consistently higher for HNA compared to LNA cells (Table 2). In the control and reduced flagellates treatments, cellspecific leucine incorporation rates for both HNA and LNA cells were generally higher at the shelf station compared to the basin station. However, in the reduced FVB treatments, cell-specific leucine incorporation rates of HNA cells at the basin station were at least twice the cell-specific leucine incorporation rates measured at the shelf station by Day 2 of the experiment (Table 2).

Cell-specific leucine incorporation rates were compared to side scatter and SYBR fluorescence (a proxy for cell nucleic acid content). Cell-specific leucine incorporation rates were significantly and positively correlated to side scatter for HNA cells at both the shelf and basin stations (Pearson correlation; shelf: $\mathrm{r}=0.7$, $\mathrm{p}=0.0006$; basin: $\mathrm{r}=0.95, \mathrm{p}<<0.0001)$. However, there were no significant correlations between side scatter and leucine incorporation rates of LNA cells, nor were there any significant correlations between cell-specific incorporation rates and SYBR fluorescence for either HNA or LNA cells.

Comparing cell-specific leucine incorporation rates in the reduced mortality treatments relative to the rates in the control treatments revealed different patterns at the shelf station compared to the basin station (Table 2). There were changes in the cell-specific 


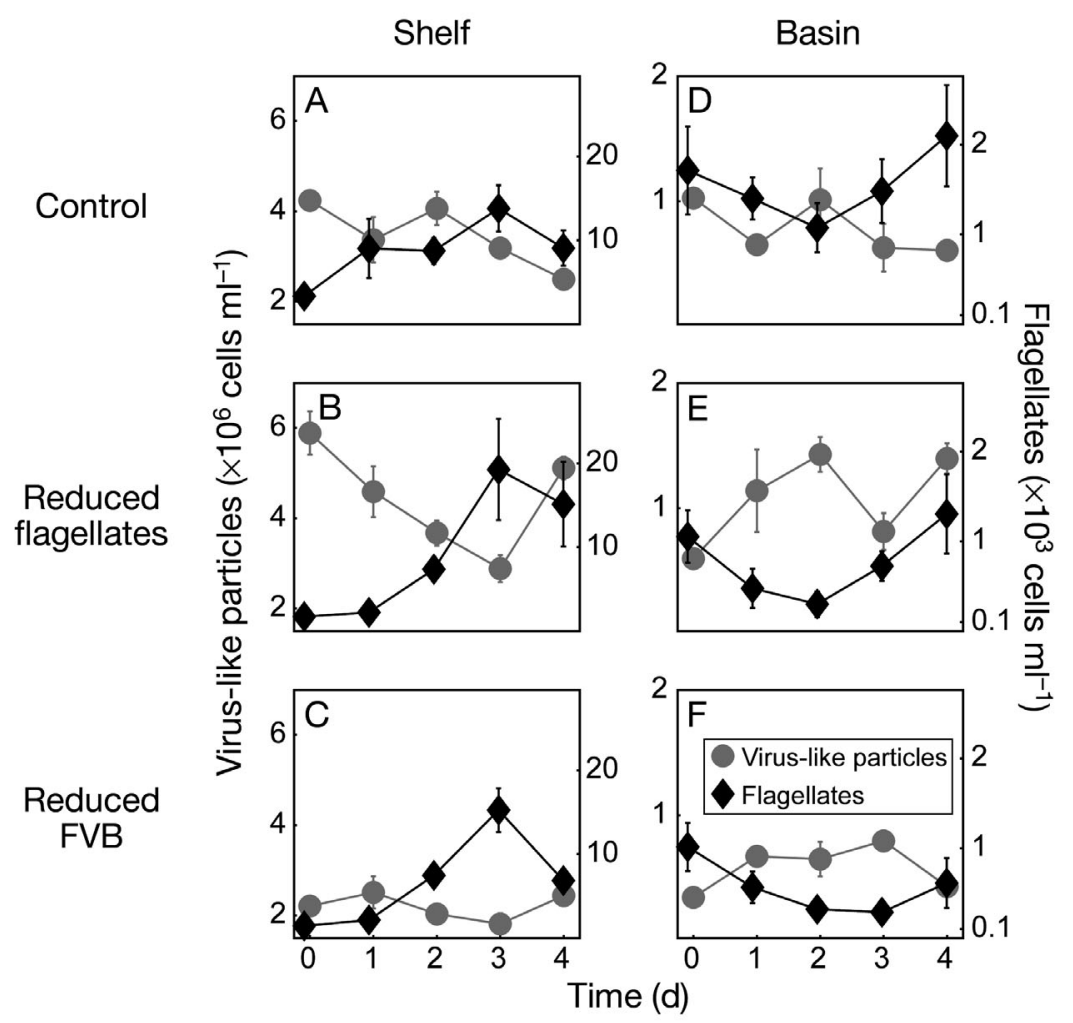

Fig. 3. Abundances of virus-like particles (left axes, $\times 10^{6}$ cells $\mathrm{ml}^{-1}$ ) and flagellates (right axes, $\times 10^{3}$ cells $\mathrm{ml}^{-1}$ ). Note the difference in scale between the shelf $(\mathrm{A}-\mathrm{C})$ and basin station data $(\mathrm{D}-\mathrm{F})$. Three different treatments are shown: $(A, D)$ control, $(B, E)$ reduced flagellates, and $(C, F)$ reduced flagellates/ viruses/bacterioplankton (FVB). Viral abundances were obtained using flow cytometry; flagellate abundances are counts from epifluorescence microscopy

Table 2. Shelf and basin cell-specific leucine incorporation rates for high (HNA) and low nucleic acid (LNA) cells. Data are mean (SE) cell-specific incorporation rates; units are $10^{-21} \mathrm{~mol}$ leucine cell ${ }^{-1} \mathrm{~h}^{-1}$. Three replicate sorts were conducted for each treatment at each time point. FVB: flagellates/virus/bacterioplankton

\begin{tabular}{|c|c|c|c|c|c|}
\hline \multirow[t]{2}{*}{ Treatment } & \multirow[t]{2}{*}{ Time (d) } & \multicolumn{2}{|c|}{ Shelf } & \multicolumn{2}{|c|}{ Basin } \\
\hline & & HNA & LNA & HNA & LNA \\
\hline \multirow[t]{5}{*}{ Control } & 0 & $103(16)$ & $35(9)$ & $28(1)$ & $12(2)$ \\
\hline & 1 & 114 (15) & 64 (10) & $60(8)$ & $8(1)$ \\
\hline & 2 & 66 (15) & $38(4)$ & $88(4)$ & $17(2)$ \\
\hline & 3 & $140(12)$ & $33(2)$ & $48(13)$ & $18(2)$ \\
\hline & 4 & $202(4)$ & $47(7)$ & 67 (1) & $19(4)$ \\
\hline \multirow{5}{*}{$\begin{array}{l}\text { Reduced } \\
\text { flagellates }\end{array}$} & 0 & $86(28)$ & $37(7)$ & $15(1)$ & $4(0)$ \\
\hline & 1 & 223 (15) & $58(11)$ & $92(11)$ & $10(2)$ \\
\hline & 2 & $138(17)$ & $39(7)$ & $125(39)$ & $28(7)$ \\
\hline & 3 & $118(11)$ & $17(4)$ & $201(6)$ & $22(3)$ \\
\hline & 4 & $236(24)$ & 64 (12) & $100(33)$ & $8(1)$ \\
\hline \multirow[t]{5}{*}{ Reduced FVB } & 0 & $104(8)$ & $32(2)$ & $26(4)$ & $15(2)$ \\
\hline & 1 & $196(33)$ & 91 (9) & $157(20)$ & $8(0)$ \\
\hline & 2 & $71(10)$ & $27(6)$ & $306(40)$ & $10(0)$ \\
\hline & 3 & $146(24)$ & $20(2)$ & 410 (37) & $16(2)$ \\
\hline & 4 & $127(22)$ & $44(5)$ & $293(57)$ & 36 (9) \\
\hline
\end{tabular}

leucine incorporation rates in the controls; however, larger changes for the HNA cells were observed in both the reduced flagellates and reduced FVB treatments. The largest difference in HNA cell-specific leucine incorporation rates was in the reduced FVB container at the basin station, where the cell-specific leucine incorporation rate was 8 -fold higher compared to values obtained in the control. While LNA cells did exhibit changes in cellspecific leucine incorporation over the course of the experiment (Table 2), there were no significant differences between the controls and the reduced flagellates or reduced FVB treatments for LNA cells (Kruskal-Wallis, $\mathrm{p} \geq 0.4$ ).

\section{Diversity of metabolically active bacterioplankton}

Subsets of the samples collected during the experiment were processed via MICROFISH analysis. We did not examine how filtration altered the bacterial community composition relative to the in situ water conditions. At the shelf station, samples through Day 2 were selected, while the basin station included samples from Days 0, 2, and 3. After these times, bacterial abundance decreased in both experiments. The sum of the abundances from the 4 bacterial probes (ALF968, Bet42a, CFB319a, and Gam42a) identified $30 \%(95 \% \mathrm{CI}=21$ to $39 \%)$ of DAPIstained cells in the samples at the shelf station and $41 \%$ (95\% CI = 32 to $50 \%$ ) of DAPI-stained cells at the basin station. At the beginning of the experiment, the bacterial community at the shelf station in the control was dominated by Gam42a-labeled cells (47\% of Cy3-labeled cells) and CFB319a (32\%), while ALF968 and Bet42a both represented $11 \%$ of the Cy3-labeled cells. In the control treatment at the basin station, cells labeled with the Gam42a probe comprised the majority of cells identified by the Cy3 probes (38\% of cells identified), with lesser contributions from ALF968 (18\%), Bet42a (23\%), and CFB319a (21\%). 


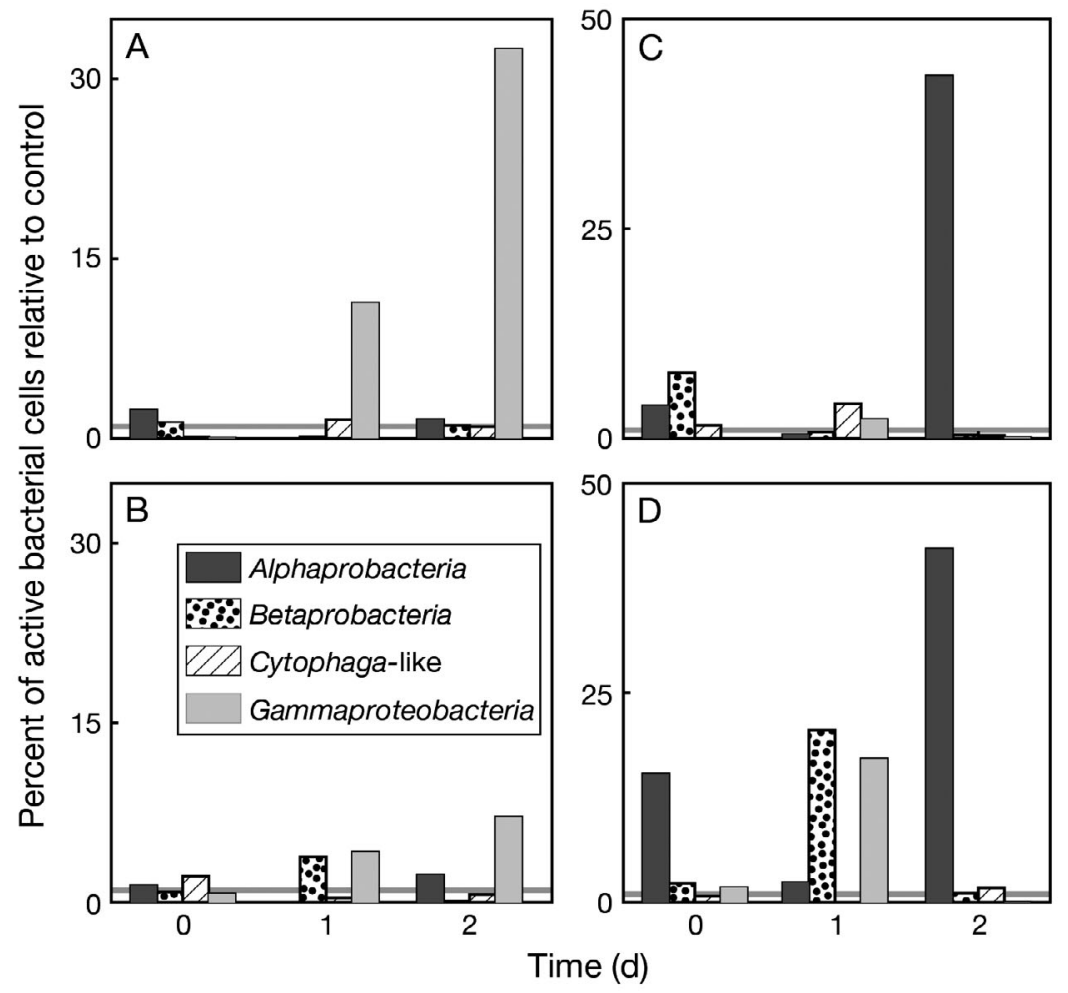

Fig. 4. Percent of bacterial cells assimilating leucine for each of the probelabeled bacterial groups normalized to values obtained for the same group in the control. These data only consider the abundance of cells assimilating leucine and not the amount of leucine each group might have assimilated. Note the difference in scales between the shelf $(A, B)$ and basin station data $(C, D)$. Gray horizontal lines indicate no difference in the percent of active cells in the control and the reduced flagellates $(\mathrm{A}, \mathrm{C})$ or reduced flagellates/viruses/ bacterioplankton $(\mathrm{FVB})$ treatments $(\mathrm{B}, \mathrm{D})$ labeled with the ALF968 probe comprised the majority of the active community in the reduced flagellates treatment (Fig. 4C). In the reduced FVB treatment (Fig. 4D), both ALF968- and Bet42a-labeled cells made up a larger fraction of the active community by Day 2 of the experiment, although by Day 3 only the ALF968-labeled cells were more active relative to the control.

\section{Linking MICROFISH data with cell-specific leucine incorporation rates}

At the basin station, abundances of active cells labeled with the Bet42a and CFB319a probes were significantly negatively correlated to cellspecific leucine incorporation rates for HNA cells (Spearman rank correlations; Bet42a: $\mathrm{r}=-0.88, \mathrm{p}=0.003$; CFB319a: $r=-0.88, p=0.003)$. No significant correlations were observed between the abundances of active cells and leucine incorporation rates at the shelf station, nor were the correlations with the leucine incorporation rates of LNA cells significant.

\section{DISCUSSION}

leucine to be scored positive by microautoradiography were considered metabolically active cells. At the shelf station, $21 \%$ (95\% CI = 12 to $30 \%$ ) of all DAPI-stained cells were scored as metabolically active compared to $40 \%$ (95\% CI $=31$ to $49 \%$ ) at the basin station. Considering all of the bacterial probes, a significantly higher proportion of probe-stained cells were metabolically active at the basin station $(52 \%, 95 \% \mathrm{CI}=43$ to $61 \%) \mathrm{com}$ pared to the shelf station $(19 \%, 95 \% \mathrm{CI}=10$ to $28 \%)$.

The diversity of metabolically active cells in both the reduced flagellates and reduced FVB treatments changed relative to the diversity observed in the control. The percent of active cells for each phylogenetic group was therefore divided by the percent of active cells in that group observed in the control (Fig. 4). Larger increases in the percent of active cells were observed at the basin station compared to the shelf station. At the shelf station, active cells labeled with the Gam42a probe dominated in both the reduced flagellates (Fig. 4A) and reduced FVB treatments (Fig. 4B) relative to the control. At the basin station, cells
The high variability in trophic state over short geographic distances in the Oregon coastal upwelling system (Huyer et al. 2007, Keister \& Strub 2008) make this coastal region an excellent location for evaluating factors controlling abundance and activity of heterotrophic marine bacterioplankton. During the summer upwelling season, the shelf region is characterized by sporadic diatom blooms; farther offshore there are lower chl a concentrations and a phytoplankton community primarily composed of $<5 \mu \mathrm{m}$ cells (Sherr et al. 2005). Although variability in the autotrophic community may partially explain spatial variability in bacterial abundance and activity in this region (Sherr et al. 2001, 2006), it did not affect the spatial variability in phylogenetic diversity of metabolically active bacterioplankton at the shelf station compared to the basin station (Longnecker et al. 2006a). This suggested that bottom-up control was not a main factor structuring the diversity of the metabolically active bacterial community off the Oregon coast. 
The relative roles of top-down and bottom-up control may vary with ecosystem trophic state, although published data are equivocal on this issue. Furthermore, concurrent changes in nutrient availability and predation further complicate interpretion of the effect of predation on a bacterial community (Corno \& Jürgens 2008). Modeling results have indicated top-down control of bacterial abundance is more important in eutrophic marine environments (Sanders et al. 1992, Thelaus et al. 2008). However, a compilation of model and experimental results indicated the opposite: topdown control of marine bacterioplankton abundance was greater in oligotrophic systems (Gasol et al. 2002). To our knowledge, the present study is the first to examine how top-down control in a marine ecosystem specifically affects the metabolically active component of marine bacterioplankton.

Reducing both potential top-down processes, protist grazing and viral infection, had a greater effect on the cell-specific activity of substrate-active bacterioplankton at the oligotrophic basin station than at the eutrophic shelf station. At the basin station, cell-specific leucine incorporation by HNA cells and HNA cell size both increased when top-down control was reduced. The dominance of HNA cells and the limited response of LNA cells under reduced top-down control at the basin station suggest that grazers and viral infection have a greater impact on HNA than LNA cells. Yet even in the eutrophic shelf region of the Oregon upwelling system, protist grazers may affect both bacterial abundances and rates of dissolved organic carbon degradation (Wetz et al. 2008), which highlights the limited state of our knowledge with respect to interactions between grazers and their metabolically active bacterial prey.

The transient increase in the abundance of LNA cells at the shelf station in the reduced flagellates and reduced FVB treatments was not surprising. Our previous work in the Oregon upwelling system has noted LNA cells can be a significant component of bacterial leucine incorporation at oligotrophic stations (Longnecker et al. 2005, 2006b), and that LNA cells can increase in abundance in dilution experiments (Longnecker et al. 2007, K. Longnecker et al. unpubl. data). In the Oregon upwelling system (Longnecker et al. 2005) and the Mediterranean (Servais et al. 2003), small or no phylogenetic differences have been observed between HNA and LNA cells. However, Zubkov et al. (2001a,b) have observed phylogenetic differences between HNA and LNA cells. Therefore, we cannot rule out the possibility that a phylogenetic shift could have caused the short-term increase in the abundance of LNA cells, although this was not observed in the present study.

In terms of activity of specific phylogenetic groups of bacterioplankton, in the present study the proportion of metabolically active cells relative to the control was highest for Gammaproteobacteria at the shelf station and Alphaproteobacteria at the basin station. Assessments of bulk bacterial diversity have revealed that Gammaproteobacteria are able to benefit from reduced flagellate pressure (Suzuki 1999, Beardsley et al. 2003). Furthermore, in a freshwater reservoir, even though Gammaproteobacteria represented $<5 \%$ of the bacterial community, $80 \%$ of Gammaproteobacteria scored positive for assimilation of leucine when grazers were removed (Hornák et al. 2008). In separate experiments carried out during our 2004 cruise off the Oregon coast, we observed that the bacterial community composition after $3 \mathrm{~d}$ of growth in $0.8 \mu \mathrm{m}$-filtered seawater was predominantly Gammaproteobacteria in both shelf and basin station incubations (Longnecker et al. 2007, K. Longnecker et al. unpubl. data). However, dilution experiments conducted in the western North Pacific provided no evidence of differences in grazing mortality between Gammaproteobacteria and other bacterial groups (Yokokawa \& Nagata 2005), suggesting that we do not fully understand how Gammaproteobacteria are able to grow faster than other groups of bacterioplankton under conditions of reduced grazing. Furthermore, even within Gammaproteobacteria, different genera have different responses to substrate addition (Pernthaler et al. 2001), and such variability within a phylogenetic group complicates our understanding of metabolic activity in marine ecosystems.

Viruses can play a large role in structuring bacterial diversity in oligotrophic oceans by differentially affecting the phylogenetic groups present in a given assemblage (Hewson \& Fuhrman 2007). For example, lysis of bacterial cells provides dissolved organic matter (substrate) which can enhance the growth of other bacterial groups (Weinbauer \& Rassoulzadegan 2004, Middelboe \& Jørgensen 2006). However, decreases in bacterial growth due to viral lysis have been found to vary among different phylogenetic groups (Weinbauer et al. 2006). In coastal Oregon, Bouvier \& del Giorgio (2007) demonstrated that Betaproteobacteria dominated the shelf region in virus-depleted treatments while Gammaproteobacteria comprised the largest proportion of the bacterial community at the oligotrophic station, whether or not viruses were present. In the present study, reducing viral abundance in the shelf experiment did not cause large increases in the percent of active cells relative to changes already observed in the treatments with a reduced number of grazers. Therefore, the diversity of active bacterioplankton responded primarily to the reduction of grazers with little additional effect observed when viruses were also reduced. 
Decreasing viral abundance in water from the oligotrophic station did affect bacterial cell-specific activity. The interactions between viruses, grazers, and bacterial cells have been examined in oligotrophic freshwater experiments (Sime-Ngando \& Pradeep Ram 2005, Pradeep Ram \& Sime-Ngando 2008). These experiments have revealed that the frequency of bacterial cells containing viruses is higher in the presence of grazers (Sime-Ngando \& Pradeep Ram 2005), and that nutrient addition causes further increases in the frequency of bacterial cells containing viruses (Pradeep Ram \& Sime-Ngando 2008). However, the interaction between viruses and HNA cells in particular has received less attention compared to interactions between HNA cells and protozoan grazers. In the present study, we observed a large increase in cell-specific leucine incorporation by HNA cells only in the presence of lower viral abundances at the oligotrophic basin station. Thus our data support the idea that viruses target HNA cells to a greater degree in oligotrophic systems (Lebaron et al. 2001). One hypothesis for our results is that the reduction in viruses at the basin station was sufficient to reduce encounter rates between viruses and their bacterial hosts such that HNA cells were able to use more substrate for biomass production and less for production of viral particles. While the present study provides evidence that viruses alter cell-specific activity in oligotrophic regions, more work is needed to identify the mechanism by which viruses affect bacterial metabolic activity and whether it is linked to the frequency of HNA cells containing viruses.

We could not quantify leucine incorporation by each phylogenetic group because our data only indicate the proportion of group-specific bacterial cells assimilating leucine and not the cell-specific amount of leucine each bacterial group assimilated. However, we did observe significant negative correlations at the basin station between cell-specific leucine incorporation by HNA cells and abundances of Gammaproteobacteria and Cytophaga-like cells. Recent methodological developments (Orphan et al. 2002, Pearson et al. 2008) may provide the potential to quantify metabolic activity of targeted phylogenetic groups in future studies. The activity of aquatic bacterioplankton exists on a continuum (Smith \& del Giorgio 2003), thus there is no reason to think that bacterial activity will be constant across any one phylogenetic group.

Experimental manipulations such as those conducted in the present study are not without problems with respect to interpretation of the data and inferences made about in situ processes. We did not track in situ variability in the bacterial community during this experiment. However, confining microbial populations in containers is known to alter both bacterial diversity (Massana et al. 2001, Agis et al. 2007) and cell-specific activity relative to in situ values (Ferguson et al. 1984, Sherr et al. 1999b). In addition, the filtration methods we used to size-fractionate the community could have resulted in the rupture of microbial cells and thereby altered the concentration and composition of dissolved organic matter in the water used to establish the incubations (Fuhrman \& Bell 1985, Goldman \& Dennett 1985, Giovannoni et al. 1990). Finally, the reduced FVB treatment was also a reduced grazer treatment. While it is easier to consider the effect of viral lysis separately from flagellate grazing, these 2 forms of top-down control can interact with each other in a manner that affects the bacterial community (Weinbauer et al. 2007, Zhang et al. 2007).

In conclusion, the present study used experimental manipulations to examine the role of top-down control in structuring both cell-specific activity and diversity of metabolically active bacterioplankton. Our data revealed the metabolically active bacterial community at the oligotrophic basin station responded more strongly to reductions in top-down control compared to the community at the eutrophic shelf station. This supports previous research that top-down control is more relevant in oligotrophic compared to eutrophic ecosystems (Gasol et al. 2002). Our experiments expand on that idea by revealing that the form of top-down control in oligotrophic regions is important to consider. Removing grazers altered the diversity of active cells. Conversely, reducing viruses impacted cell-specific activity but did not cause additional changes in the diversity of active bacterioplankton. Determining the mechanism by which grazers and/or viruses alter bacterial cell-specific activity and diversity is beyond the scope of the present study. However, our results indicate that both the presence and form of top-down control are important considerations when seeking to explain factors controlling metabolically active marine bacterioplankton.

Acknowledgements. We thank E. J. Etherington, A. J. Hartz, S. M. Sowell, S. Starr, and A. Thorp for assistance in establishing and sampling the microcosms. J. Jennings and K. Landgren assisted in sample processing on shore. The help of the captain, crew, and marine technicians of the RV 'Wecoma' both before and during the cruise is appreciated. We also appreciate the comments of 2 anonymous reviewers and the editor, K. Jürgens, which greatly improved this paper. The flow cytometer was acquired via NSF Major Research Instrumentation Grant OCE-0078908. This research was funded by OCE-0240785 to B.F.S. and E.B.S.

\section{LITERATURE CITED}

Agis M, Granda A, Dolan JR (2007) A cautionary note: examples of possible microbial community dynamics in dilution grazing experiments. J Exp Mar Biol Ecol 341: 176-183 
Alonso-Sáez L, Gasol JM (2007) Seasonal variations in the contributions of different bacterial groups to the uptake of low-molecular-weight compounds in northwestern Mediterranean coastal waters. Appl Environ Microbiol 73: 3528-3535

Amann RI, Binder BJ, Olson RJ, Chisholm SW, Devereux R, Stahl DA (1990) Combination of 16S rRNA-targeted oligonucleotide probes with flow cytometry for analyzing mixed microbial populations. Appl Environ Microbiol 56: 1919-1925

Beardsley C, Pernthaler J, Wosniok W, Amann R (2003) Are readily culturable bacteria in coastal North Sea waters suppressed by selective grazing mortality? Appl Environ Microbiol 69:2624-2630

Bevington PR, Robinson DK (2003) Data reduction and error analysis for the physical sciences, 3rd edn. McGraw Hill, San Francisco, CA

Bouvier T, del Giorgio PA (2007) Key role of selective viralinduced mortality in determining marine bacterial community composition. Environ Microbiol 9:287-297

Brussaard CPD (2004) Optimization of procedures for counting viruses by flow cytometry. Appl Environ Microbiol 70: 1506-1513

Clasen JL, Brigden SM, Payet JP, Suttle CA (2008) Evidence that viral abundance across oceans and lakes is driven by different biological factors. Freshw Biol 53: $1090-1100$

Corno G, Jürgens K (2008) Structural and functional patterns of bacterial communities in response to protist predation along an experimental productivity gradient. Environ Microbiol 10:2857-2871

> Cottrell MT, Kirchman DL (2000) Natural assemblages of marine Proteobacteria and members of the CytophagaFlavobacter cluster consuming low- and high-molecularweight dissolved organic matter. Appl Environ Microbiol 66:1692-1697

del Giorgio PA, Bouvier TC (2002) Linking the physiologic and phylogenetic successions in free-living bacterial communities along an estuarine salinity gradient. Limnol Oceanogr 47:471-486

del Giorgio PA, Gasol JM (2008) Physiological structure and single-cell activity in marine bacterioplankton. In: Kirchman DL (ed) Microbial ecology of the oceans. Wiley, New York, p 243-298

del Giorgio PA, Gasol JM, Vaqué D, Mura P, Agustí S, Duarte CM (1996) Bacterioplankton community structure: protists control net production and the proportion of active bacteria in a coastal marine community. Limnol Oceanogr 41: 1169-1179

Elifantz H, Dittel AI, Cottrell MT, Kirchman DL (2007) Dissolved organic matter assimilation by heterotrophic bacterial groups in the western Arctic Ocean. Aquat Microb Ecol 50:39-49

Ferguson RL, Buckley EN, Palumbo AV (1984) Response of marine bacterioplankton to differential filtration and confinement. Appl Environ Microbiol 47:49-55

Fuhrman JA (1999) Marine viruses and their biogeochemical and ecological effects. Nature 399:541-548

Fuhrman JA, Bell TM (1985) Biological considerations in the measurement of dissolved free amino acids in seawater and implications for chemical and microbiological studies. Mar Ecol Prog Ser 25:13-21

Fuhrman JA, Noble RT (1995) Viruses and protists cause similar bacterial mortality in coastal seawater. Limnol Oceanogr 40:1236-1242

> Gasol JM, del Giorgio PA (2000) Using flow cytometry for counting natural planktonic bacteria and understanding the structure of planktonic bacterial communities. Sci Mar 64:197-224

Gasol JM, Pedrós-Alió C, Vaqué D (2002) Regulation of bacterial assemblages in oligotrophic plankton systems: results from experimental and empirical approaches. Antonie Leeuwenhoek 81:435-452

Giovannoni SJ, DeLong EF, Schmidt TM, Pace NR (1990) Tangential flow filtration and preliminary phylogenetic analysis of marine picoplankton. Appl Environ Microbiol 56:2572-2575

Glöckner FO, Fuchs BM, Amann R (1999) Bacterioplankton compositions of lakes and oceans: a first comparison based on fluorescence in situ hybridization. Appl Environ Microbiol 65:3721-3726

Goldman JC, Dennett MR (1985) Susceptibility of some marine phytoplankton species to cell breakage during filtration and post-filtration rinsing. J Exp Mar Biol Ecol 86: $47-58$

González JM (1996) Efficient size-selective bacterivory by phagotrophic nanoflagellates in aquatic ecosystems. Mar Biol 126:785-789

González JM, Sherr EB, Sherr BF (1993) Differential feeding by marine flagellates on growing versus starving, and on motile versus non-motile, bacterial prey. Mar Ecol Prog Ser 102:257-267

Gordon LI, Jennings JC, Ross AA, Krest JM (1994) A suggested protocol for continuous flow automated analysis of seawater nutrients (phosphate, nitrate, nitrite and silicic acid) in the WOCE Hydrographic Program and the Joint Global Ocean Fluxes Study. WOCE Operations Manual, WOCE Report No 68/91 Revision 1. Woods Hole Oceanographic Institute, Woods Hole, MA

Hewson I, Fuhrman JA (2007) Covariation of viral parameters with bacterial assemblage richness and diversity in the water column and sediments. Deep-Sea Res I 54: 811-830

> Hornák K, Jezbera J, Šimek K (2008) Effects of a Microcystis aeruginosa bloom and bacterivory on bacterial abundance and activity in a eutrophic reservoir. Aquat Microb Ecol 52:107-117

> Huyer A, Wheeler PA, Strub PT, Smith RL, Letelier R, Kosro PM (2007) The Newport line off Oregon-studies in the north east Pacific. Prog Oceanogr 75:126-160

> Jochem FJ, Lavrentyev PJ, First MR (2004) Growth and grazing rates of bacteria groups with different apparent DNA content in the Gulf of Mexico. Mar Biol 145:1213-1226

Jürgens K, Matz C (2002) Predation as a shaping force for the phenotypic and genotypic composition of planktonic bacteria. Antonie Leeuwenhoek 81:413-434

Karner M, Fuhrman JA (1997) Determination of active marine bacterioplankton: a comparison of universal 16S rRNA probes, autoradiography, and nucleoid staining. Appl Environ Microbiol 63:1208-1213

Keister JE, Strub PT (2008) Spatial and interannual variability in mesoscale circulation in the northern California Current System. J Geophys Res 113:C04015

Kirchman DL (1993) Leucine incorporation as a measure of biomass production by heterotrophic bacteria. In: Kemp PF, Sherr BF, Sherr EB, Cole JJ (eds) Current methods in aquatic microbial ecology. Lewis Publishing, New York, p 509-512

> Lebaron P, Servais P, Agogué H, Courties C, Joux F (2001) Does the high nucleic acid content of individual bacterial cells allow us to discriminate between active cells and inactive cells in aquatic systems? Appl Environ Microbiol 67:1775-1782

> Lebaron P, Servais P, Baudoux AC, Bourrain M, Courties C, Parthuisot N (2002) Variations of bacterial-specific activity 
with cell size and nucleic acid content assessed by flow cytometry. Aquat Microb Ecol 28:131-140

Li WKW, Jellett JF, Dickie PM (1995) DNA distributions in planktonic bacteria stained with TOTO or TO-PRO. Limnol Oceanogr 40:1485-1495

Longnecker K, Sherr BF, Sherr EB (2005) Activity and phylogenetic diversity of high and low nucleic acid content, and ETS-active, bacterial cells in an upwelling ecosystem. Appl Environ Microbiol 71:7737-7749

Longnecker K, Homen DS, Sherr EB, Sherr BF (2006a) Similar community structure of biosynthetically active prokaryotes across a range of ecosystem trophic states. Aquat Microb Ecol 42:265-276

> Longnecker K, Sherr BF, Sherr EB (2006b) Variation in cellspecific rates of leucine and thymidine incorporation by high and low nucleic acid content marine bacteria off the Oregon coast. Aquat Microb Ecol 43:113-125

Longnecker K, Sherr EB, Sherr BF (2007) Linking the growth of marine heterotrophic bacterioplankton with changes in the dominant phytoplankton community. ASLO Aquatic Sciences Meeting, Santa Fe, NM, 4-9 Feb 2007

Manz W, Amann R, Ludwig W, Wagner M, Schleifer KH (1992) Phylogenetic oligodeoxynucleotide probes for the major subclasses of Proteobacteria: problems and solutions. Syst Appl Microbiol 15:593-600

Marie D, Partensky F, Jacquet S, Vaulot D (1997) Enumeration and cell cycle analysis of natural populations of marine picoplankton by flow cytometry using the nucleic acid stain SYBR Green I. Appl Environ Microbiol 63: 186-193

Marie D, Brussaard CPD, Thyrhaug R, Bratbak G, Vaulot D (1999) Enumeration of marine viruses in culture and natural samples by flow cytometry. Appl Environ Microbiol 65:45-52

Mary I, Heywood JL, Fuchs BM, Amann R, Tarran GA, Burkill PH, Zubkov MV (2006) SAR11 dominance among metabolically active low nucleic acid bacterioplankton in surface waters along an Atlantic meridional transect. Aquat Microb Ecol 45:107-113

Massana R, Pedrós-Alió C, Casamayor EO, Gasol JM (2001) Changes in marine bacterioplankton phylogenetic composition during incubations designed to measure biogeochemically significant parameters. Limnol Oceanogr 46: $1181-1188$

Middelboe M, Jørgensen NOG (2006) Viral lysis of bacteria: an important source of dissolved amino acids and cell wall compounds. J Mar Biol Assoc UK 86:605-612

Miki T, Jacquet S (2008) Complex interactions in the microbial world: underexplored key links between viruses, bacteria and protozoan grazers in aquatic environments. Aquat Microb Ecol 51:195-208

Monger BC, Landry MR (1992) Size-selective grazing by heterotrophic nanoflagellates: an analysis using live-stained bacteria and dual-beam flow cytometry. Arch Hydrobiol 37:173-185

> Orphan VJ, House CH, Hinrichs KU, McKeegan KD, DeLong EF (2002) Multiple archaeal groups mediate methane oxidation in anoxic cold seep sediments. Proc Natl Acad Sci USA 99:7663-7668

Ouverney CC, Fuhrman JA (1999) Combined microautoradiography-16S rRNA probe technique for determination of radioisotope uptake by specific microbial cell types in situ. Appl Environ Microbiol 65:1746-1752

Pearson A, Kraunz KS, Sessions AL, Dekas AE, Leavitt WD, Edwards KJ (2008) Quantifying microbial utilization of petroleum hydrocarbons in salt marsh sediments by using the ${ }^{13} \mathrm{C}$ content of bacterial rRNA. Appl Environ Microbiol 74:1157-1166
Pernthaler A, Pernthaler J, Eilers H, Amann R (2001) Growth patterns of two marine isolates: adaptations to substrate patchiness. Appl Environ Microbiol 67:4077-4083

Pradeep Ram AS, Sime-Ngando T (2008) Functional responses of prokaryotes and viruses to grazer effects and nutrient additions in freshwater microcosms. ISME J 2: 498-509

Sanders RW, Caron DA, Berninger UG (1992) Relationships between bacteria and heterotrophic nanoplankton in marine and fresh waters: an inter-ecosystem comparison. Mar Ecol Prog Ser 86:1-14

Scharek R, Latasa M (2007) Growth, grazing and carbon flux of high and low nucleic acid bacteria differ in surface and deep chlorophyll maximum layers in the NW Mediterranean Sea. Aquat Microb Ecol 46:153-161

Servais P, Courties C, Lebaron P, Troussellier M (1999) Coupling bacterial activity measurements with cell sorting by flow cytometry. Microb Ecol 38:180-189

Servais P, Casamayor EO, Courties C, Catala P, Parthuisot N, Lebaron P (2003) Activity and diversity of bacterial cells with high and low nucleic acid content. Aquat Microb Ecol 33:41-51

> Seymour JR, Patten N, Bourne DG, Mitchell JG (2005) Spatial dynamics of virus-like particles and heterotrophic bacteria within a shallow coral reef system. Mar Ecol Prog Ser 288: $1-8$

Sherr EB, Sherr BF (1993) Preservation and storage of samples for enumeration of heterotrophic protists. In: Kemp PF, Sherr BF, Sherr EB, Cole JJ (eds) Handbook of methods in aquatic microbial ecology. Lewis Publishers, Boca Raton, FL, p 207-212

> Sherr BF, Sherr EB, McDaniel J (1992) Effect of protistan grazing on the frequency of dividing cells in bacterioplankton assemblages. Appl Environ Microbiol 58: 2381-2385

Sherr EB, Caron DA, Sherr BF (1993) Staining of heterotrophic protists for visualization via epifluorescence microscopy. In: Kemp PF, Sherr BF, Sherr EB, Cole JJ (eds) Handbook of methods in aquatic microbial ecology. Lewis Publishers, Boca Raton, FL, p 213-228

> Sherr BF, del Giorgio P, Sherr EB (1999a) Estimating abundance and single-cell characteristics of respiring bacteria via the redox dye CTC. Aquat Microb Ecol 18:117-131

Sherr EB, Sherr BF, Sigmon CT (1999b) Activity of marine bacteria under incubated and in situ conditions. Aquat Microb Ecol 20:213-223

Sherr EB, Sherr BF, Cowles TJ (2001) Mesoscale variability in bacterial activity in the Northeast Pacific Ocean off Oregon, USA. Aquat Microb Ecol 25:21-30

Sherr EB, Sherr BF, Wheeler PA (2005) Distribution of coccoid cyanobacteria and small eukaryotic phytoplankton in the upwelling ecosystem off the Oregon coast during 2001 and 2002. Deep-Sea Res II 52:317-330

> Sherr EB, Sherr BF, Longnecker K (2006) Distribution of bacterial abundance and cell-specific nucleic acid content in the Northeast Pacific Ocean. Deep-Sea Res I 53: 713-725

> Sime-Ngando T, Pradeep Ram AS (2005) Grazer effects on prokaryotes and viruses in a freshwater microcosm experiment. Aquat Microb Ecol 41:115-124

Šimek K, Weinbauer MG, Hornák K, Jezbera J, Nedoma J, Dolan JR (2007) Grazer and virus-induced mortality of bacterioplankton accelerates development of Flectobacillus populations in a freshwater community. Environ Microbiol 9:789-800

Smith EM, del Giorgio PA (2003) Low fractions of active bacteria in natural aquatic communities? Aquat Microb Ecol 31:203-208 
Strickland JDH, Parsons TR (1972) A practical handbook of seawater analysis, 2nd edn. Fisheries Research Board of Canada, Ottawa

Strom SL (2008) Microbial ecology of ocean biogeochemistry: a community perspective. Science 320:1043-1045

Suttle CA (2007) Marine viruses - major players in the global ecosystem. Nat Rev Microbiol 5:801-812

Suzuki MT (1999) Effect of protistan bacterivory on coastal bacterioplankton diversity. Aquat Microb Ecol 20:261-272

Thelaus J, Haecky P, Forsman M, Andersson A (2008) Predation pressure on bacteria increases along aquatic productivity gradients. Aquat Microb Ecol 52:45-55

Troussellier M, Courties C, Lebaron P, Servais P (1999) Flow cytometric discrimination of bacterial populations in seawater based on SYTO 13 staining of nucleic acids. FEMS Microbiol Ecol 29:319-330

Vaqué D, Casamayor EO, Gasol JM (2001) Dynamics of whole community bacterial production and grazing losses in seawater incubations as related to the changes in the proportions of bacteria with different DNA content. Aquat Microb Ecol 25:163-177

- Varela MM, van Aken HM, Sintes E, Herndl GJ (2008) Latitudinal trends of Crenarchaeota and Bacteria in the mesoand bathypelagic water masses of the Eastern North Atlantic. Environ Microbiol 10:110-124

Vázquez-Domínguez E, Casamayor EO, Català P, Lebaron P (2005) Different marine heterotrophic nanoflagellates affect differentially the composition of enriched bacterial communities. Microb Ecol 49:474-485

Weinbauer MG, Rassoulzadegan F (2004) Are viruses driving microbial diversification and diversity? Environ Microbiol 6:1-11

> Weinbauer MG, Christaki U, Nedoma J, Šimek K (2003) Comparing the effects of resource enrichment and grazing on viral production in a meso-eutrophic reservoir. Aquat Microb Ecol 31:137-144

Weinbauer MG, Christen R, Höfle MG (2006) The response of Vibrio- and Rhodobacter-related populations of the NW

Editorial responsibility: Klaus Jürgens,

Rostock, Germany
Mediterranean Sea to additions of dissolved organic matter, phages, or dilution. Microb Ecol 51:336-344

Weinbauer MG, Hornák K, Jezbera J, Nedoma J, Dolan JR, Šimek K (2007) Synergistic and antagonistic effects of viral lysis and protistan grazing on bacterial biomass, production and diversity. Environ Microbiol 9: 777-788

> Wetz MS, Hales B, Wheeler PA (2008) Degradation of phytoplankton-derived organic matter: implications for carbon and nitrogen biogeochemistry in coastal ecosystems. Estuar Coast Shelf Sci 77:422-432

- Whitman WB, Coleman DC, Wiebe WJ (1998) Prokaryotes: the unseen majority. Proc Natl Acad Sci USA 95: 6578-6583

- Wilhelm SW, Matteson AR (2008) Freshwater and marine virioplankton: a brief overview of commonalities and differences. Freshw Biol 53:1076-1089

Williams CJ, Lavrentyev PJ, Jochem FJ (2008) Bottom-up and top-down control of heterotrophic bacterioplankton growth in a phosphorus-depleted subtropical estuary, Florida Bay, USA. Mar Ecol Prog Ser 372:7-18

Yokokawa T, Nagata T (2005) Growth and grazing mortality rates of phylogenetic groups of bacterioplankton in coastal marine environments. Appl Environ Microbiol 71: 6799-6807

> Zhang R, Weinbauer MG, Qian PY (2007) Viruses and flagellates sustain apparent richness and reduce biomass accumulation of bacterioplankton in coastal marine waters. Environ Microbiol 9:3008-3018

- Zubkov MV, Fuchs BM, Archer SD, Kiene RP, Amann R, Burkill PH (2001a) Linking the composition of bacterioplankton to rapid turnover of dissolved dimethylsulphoniopropionate in an algal bloom in the North Sea. Environ Microbiol 3:304-311

Zubkov MV, Fuchs BM, Burkill PH, Amann R (2001b) Comparison of cellular and biomass specific activities of dominant bacterioplankton groups in stratified waters of the Celtic Sea. Appl Environ Microbiol 67:5210-5218

Submitted: April 9, 2009; Accepted: August 17, 2009

Proofs received from author(s): December 10, 2009 